\title{
Penerapan Literasi Sejarah dalam Pembelajaran Sejarah pada Masa Pembelajaran Jarak Jauh di SMA Negeri 30 Jakarta
}

\author{
Ayuningtias Rahman', Kurniawati ${ }^{2}$, Murni Winarsih ${ }^{3}$ \\ Pascasarjana Pendidikan Sejarah Universitas Negeri Jakarta \\ Email: AyuningtiasRahman 9915818011@mhs.unj.ac.id ${ }^{1}$, \\ kurniawati@unj.ac.id ${ }^{2}$, mwinarsih@unj.ac.id ${ }^{3}$
}

\begin{abstract}
This article aims to find out the teacher's understanding in the application of historical literacy in the history learning period of Distance Learning (PJJ) at SMA Negeri 30 Jakarta. This research uses qualitative method with case study approach. Data collection techniques used are: (1) interviews; (2) observation; and 3) field notes, with one key informant namely history teacher and supporting informant of students Grade X IPS 3. The results of the writing showed that the teacher had mastery of important aspects of historical literacy applied in historical learning in accordance with the historical literacy of Maposa and Wasserman. Nevertheless, conceptually the teacher understands the concept of historical literacy as well as traditional literacy and the level of student literacy that is still in the low category.
\end{abstract}

Keywords: Historical Literacy, Distance Learning, History Learning

\begin{abstract}
Artikel ini bertujuan untuk mengetahui pemahaman guru dalam penerapan literasi sejarah pada pembelajaran sejarah masa Pembelajaran Jarak Jauh (PJJ) di SMA Negeri 30 Jakarta. Penelitian ini menggunakan metode kualitatif dengan pendekatan studi kasus. Teknik pengumpulan data yang digunakan yaitu: (1) wawancara; (2) observasi, dan 3) catatan lapangan, dengan satu informan kunci yaitu guru sejarah dan informan pendukung siswa Kelas X IPS. Hasil dari penelitian yang dilakukan menunjukan bahwa guru telah memiliki penguasaan terhadap aspek penting literasi sejarah yang diterapkan dalam pembelajaran sejarah sesuai dengan literasi sejarah Maposa dan Wasserman. Meskipun demikian, secara pemahaman konseptual guru memahami konsep literasi sejarah sama dengan literasi tradisional serta tingkat literasi siswa yang masih dalam kategori rendah.
\end{abstract}

Kata kunci: Literasi Sejarah, Pembelajaran Jarak Jauh (PJJ), Pembelajaran Sejarah

\section{PENDAHULUAN}

Literasi sejarah adalah kemampuan yang harus dimiliki guru sejarah dalam mengembangkan pembelajaran sejarah di kelas. Keterkaitan antara literasi dengan pembelajaran sejarah sebenarnya telah populer pada kalangan guru sejarah di negara maju, namun kurang familiar di 
telinga guru sejarah di Indonesia. Konsep literasi sejarah masih dalam tahap pengembangan oleh berbagai ahli di bidang pendidikan sejarah dan ilmu sejarah.

Konsep ini pertama kali digunakan Scheiber (1978) untuk merujuk pada kompetensi yang di tampilkan seorang individu dalam memahami sejarah tidak hanya dari teks, tetapi juga dari berbagai sumber sejarah lainnya seperti gambar, simbol dan musik (Clifford, 1984). Pendapat Scheiber tentang literasi sejarah yang telah diperjuangkannya dianggap tidak mempunyai akar yang kuat sepanjang tahun 1970-an. Setelah satu dekade berlalu, konsep literasi sejarah kembali digaungkan, kali ini dikemukakan oleh Ravitch (1989) bahwa literasi sejarah mengacu pada tingkat pengetahuan konten sejarah, yaitu, akumulasi fakta tentang peristiwa masa lalu. Dia mengklaim bahwa "beberapa informasi sangat mendasar, sangat penting sehingga semua siswa harus mengetahuinya untuk memahami pembelajaran baru". Karena itu menurut pemikiran Ravitch "pengetahuan sejarah setara dengan literasi sejarah". Selanjutnya Hirsch (1988) menyebutkan bahwa, "ketidaktahuan literasi yang membuat siswa tidak dapat berkembang di dunia modern". Konsep ini beresonansi dengan dikotomi literasi/illiterasi (buta huruf). Argumennya adalah bahwa siswa harus mengetahui fakta dasar tentang "nama geografis, peristiwa bersejarah, orang-orang terkenal, pengetahuan patriotik, dan istilah ilmiah". Namun, pendapat Hirsch ini tidak disetujui oleh para ahli lainnya seperti Aronowitz dan Giroux (1991), Bennett, Ravitch, Finn dan Glazer sebagai para kaum konservatif yang merespons ancaman postmodernisme yang dirasakannya telah melemahkan meta-narasi dari yang seharusnya diketahui. 
Tahun 1991, muncul dimensi konseptualisasi baru tentang literasi khususnya literasi sejarah. Aronowitz \& Giroux (1991) memberikan pendapatnya sebagai tanggapan dari pendapat Ravitch (1989) dan Hirsch (1988). Argumen utama Aronowitz \& Giroux (1991, p. 233) adalah bahwa jika literasi sejarah dikonseptualisasikan seperti halnya dilakukan oleh Hirsch (1988) dan Ravitch (1989), maka sejarah ternyata menjadi "museum informasi yang hanya melegitimasi pandangan tertentu tentang sejarah sebagai barang suci yang dirancang untuk diterima, bukan untuk dianalisis oleh siswa". Dengan kata lain, sejarah harus menjadi wilayah perjuangan akademik dan setiap orang yang paham sejarah harus mampu ambil bagian dalam perjuangan ini. Arti dari pengertian literasi sejarah dikembangkan lebih lanjut oleh Wineburg (1991) bahwa di atas pengetahuan sejarah, seorang individu perlu dapat bekerja dengan sumber-sumber sejarah, seperti yang diharapkan dari para sejarawan profesional untuk mencapai literasi sejarah (Maposa \& Wassermann, 2009)

Konseptualisasi literasi sejarah berikutnya dikerjakan oleh Taylor (2003). Menurut Taylor, orang yang belajar sejarah harus dapat menguasai pemikiran sejarah (historical reasoning), sintesis, dan interpretasi dalam menjelaskan peristiwa-peristiwa sejarah. Pemahaman sejarah (Historical understanding) menjadi ide utama dari literasi sejarah menurut Taylor yang mengidentifikasi literasi sejarah sebagai memahami bentuk perubahan dan keberlangsungan dari waktu ke waktu (change and continuity), memahami berbagai narasi dan berurusan dengan openendedness, dan memahami konsep-konsep sejarah seperti sebab-akibat dan motivasi. Pendapat Taylor (2003) sejalan dengan Lee (2004) bahwa Seorang individu yang paham literasi sejarah harus menggambarkan 
masa lalu tidak hanya sebagai sebuah cerita, tetapi juga sebagai peta sehingga sejarah dikontekstualisasikan dalam ruang dan waktu (Lee, 2004;Maposa \& Wassermann, 2009)

Dari berbagai konsep yang berkembang mengenai literasi sejarah, Maposa dan Wasserman (2009) menyusun kerangka konseptual atau aspek penting dari konsep literasi sejarah yang terdiri dari 5 dimensi/benchmark. Dimensi tersebut adalah hasil tinjauan mereka dari berbagai konsep-konsep literasi sejarah menurut berbagai ahli yang berevolusi dari masa ke masa. Konsep literasi sejarah yang telah diringkas menunjukkan bagaimana literasi sejarah dapat dilihat dari berbagai dimensi atau benchmark, dengan masing-masing memiliki sub-dimensi yang dijabarkan pada tabel di bawah ini :

\begin{tabular}{|c|c|}
\hline Dimensi/Benchmark literasi sejarah & Sub-Dimensi \\
\hline \multirow{2}{*}{ Pengetahuan (knowledge) } & Peristiwa-Peristiwa (events) \\
\hline & Narasi-narasi (narratives) \\
\hline \multirow{7}{*}{$\begin{array}{l}\text { Konsepsi Pemahaman } \\
\text { (conceptual understanding) }\end{array}$} & Waktu (time) \\
\hline & $\begin{array}{l}\text { Sebab-akibat dan konsekuensi (causation and } \\
\text { consequence) }\end{array}$ \\
\hline & Motivasi (motivation) \\
\hline & Arti penting (significance) \\
\hline & Penilaian moral (moral judgment) \\
\hline & $\begin{array}{l}\text { Perubahan dan keberlanjutan (change and } \\
\text { continuity) }\end{array}$ \\
\hline & Empati (empathy) \\
\hline \multirow{6}{*}{ Kerja sumber (Source Work/Historical Method) } & Pencarian sumber (sourcing) \\
\hline & Corroborasi (corroboration) \\
\hline & Kontekstualisasi (contextualization) \\
\hline & Analisis (analysis) \\
\hline & Evaluasi (evaluation) \\
\hline & Penjelasan (explanation) \\
\hline \multicolumn{2}{|l|}{ Kesadaran Sejarah (historical consciousness) } \\
\hline Bahasa Sejarah (historical language) & \\
\hline
\end{tabular}

Tabel 1.1 Tolok ukur literasi sejarah menurut Maposa \& Wassermann (2009)

Maposa dan Wassermann membedakan literasi dalam sejarah dengan literasi sejarah. Literasi dalam sejarah merujuk pada kemampuan 
untuk membaca dan menulis ketika mempelajari sejarah di kelas, sementara itu literasi sejarah merujuk pada apa yang akan didapat seseorang dari mempelajari sejarah di kelas (Maposa \& Wassermann, 2009).

Menurut peneliti konsep literasi sejarah Maposa dan Wassermann (2009) tersebut dapat dijadikan acuan atau referensi oleh guru-guru di Indonesia dalam memahami konsep literasi sejarah yang nantinya akan mereka terapkan dalam pembelajaran di kelas mereka. Selain itu juga, konsep literasi sejarah Maposa dan Wasserman dianggap dapat menjadi acuan guru karena merupakan hasil dari tinjauan berbagai aspek penting dalam literasi sejarah yang merupakan pandangan para ahli sejak tahun 80-an. Hal ini menjadi dasar dilakukan penelitian mengenai penerapan literasi sejarah dalam pembelajaran sejarah dengan lokasi penelitian dilakukan di SMA Negeri 30 Jakarta pada masa PJJ sebagai kebijakan pemerintah dalam memutus mata rantai penyebaran Covid-19 di Indonesia sejak bulan Maret (Prawiyogi, Purwanugraha, Fakhry, \& Firmansyah, 2020). Kebijakan baru dalam pembelajaran ini mewajibkan guru menyusun strategi, metode dan model pembelajaran baru menyesuaikan kondisi PJJ, salah satunya dengan meningkatkan kualitas literasi sejarah. Guru harus memahami secara mendalam mengenai dimensi-dimensi literasi sejarah agar dalam menyampaikan suatu materi sejarah, guru mampu mentransfer nilai-nilai yang terkandung dalam materi sejarah tersebut secara tepat sasaran.

Dalam melakukan penelitian ini, terdapat beberapa penelitian sebelumnya yang menjadi acuan salah satunya adalah penelitian dari Rizqa Ayu Ega Winahyu (2017) yang berjudul “Literasi Informasi Dalam 
Pembelajaran Sejarah : Melahirkan Kepekaan Sosial Siswa". Penelitian ini bertujuan untuk melihat apakah literasi informasi sudah diterapkan dengan baik dalam pembelajaran sejarah di SMA. Penelitian ini menggunakan metode kualitatif deskriptif dengan hasil yang menunjukan bahwa literasi informasi sudah berjalan dengan baik diterapkan dalam pembelajaran sejarah, sehingga membangun kepekaan sosial dalam diri siswa di SMA Negeri 2 Magelang yang terlihat dari hubungan sosial yang terjalin antara guru dengan siswa tidak hanya di dalam pembelajaran tetapi juga diluar waktu belajar. Ada sikap toleransi, saling menghargai dan tolong menolong antara guru dengan siswa setelah diterapkannya literasi informasi dalam pembelajaran sejarah (Winahyu, 2017). Perbedaan penelitian ini dengan penelitian yang dijadikan acuan terletak pada fokus teori yang digunakan merujuk pada konsep literasi sejarah bukan literasi informasi, selanjutnya perbedaan terletak pada waktu pengamatan dilaksanakan dalam pembelajaran sejarah. Pengamatan dalam kegiatan pembelajaran sejarah dilakukan pada masa pandemi Covid-19.

Peneliti membatasi 2 dimensi literasi sejarah yang akan menjadi fokus penelitian yaitu, pertama pengetahuan sejarah dan kedua adalah pemahaman konseptual sejarah. Kedua dimensi tersebut menjadi dasar dari peningkatan literasi sejarah dalam pembelajaran sejarah sekaligus sebagai tujuan dalam penelitian ini melihat secara mendalam bagaimana penerapan literasi sejarah yang dilaksanakan oleh guru sejarah di SMA Negeri 30 Jakarta.

\section{METODE}

Metode yang digunakan adalah metode kualitatif dengan menggunakan pendekatan studi kasus (case study). Metode penelitian 
kualitatif adalah metode yang digunakan untuk meneliti pada kondisi obyek yang alamiah, peneliti adalah sebagai instrumen kunci, teknik pengumpulan data dilakukan secara triangulasi (penggabungan), analisis data bersifat induktif dan hasil penelitian kualitatif lebih menekankan makna daripada generalisasi (Sugiyono, 2014).

Alasan peneliti menggunakan penelitian kualitatif dengan metode studi kasus yakni merujuk pada arti studi kasus, menurut Yin (2011) pendekatan studi kasus yang digunakan dalam penelitian akan mengungkap secara menyeluruh mengenai pertanyaan-pertanyaan mengenai proses pembelajaran seperti apa, mengapa dan bagaimana (Yin, 2011). Hasil dari pertanyaan-pertanyaan tersebut diharapkan akan mampu mendeskripsikan secara jelas mengenai objek yang akan diteliti.

Prosedur pengumpulan data penelitian menggunakan teknik wawancara, observasi, dan catatan lapangan. Teknik pengumpulan data disesuaikan dengan kondisi saat dilakukan penelitian terjadi pandemi Covid-19 sehingga implementasinya disesuaikan dengan kebijakan pemerintah yaitu melakukan segala aktivitas penelitian maupun pembelajaran dalam jaringan (daring). Wawancara dilakukan pada satu orang informan kunci yakni guru sejarah dan enam orang informan pendukung yakni siswa kelas X IPS yang dilakukan di SMA Negeri 30 Jakarta dengan cara berkomunikasi melalui Whatsapp dan Google Form. Observasi dalam pembelajaran dilakukan secara daring menggunakan Google Meet, peneliti ikut serta dalam pembelajaran daring yang dilaksanakan. Selain itu, peneliti membuat catatan lapangan yang menjadi pelengkap dalam melakukan wawancara dan observasi. 
Prosedur analisis dalam penelitian ini menggunakan dua pendekatan yaitu, pertama, analisis sebelum di lapangan yang dilakukan terhadap data hasil studi pendahuluan, atau data sekunder, yang akan digunakan untuk menentukan fokus penelitian (Sugiyono, 2014). Kedua, analisis di lapangan dengan menggunakan Model Miles dan Huberman yang diharapkan melalui tiga alur, yaitu (1) Reduksi data; (2) Penyajian data; dan (3) Penarikan kesimpulan (Milles \& Huberman, 1994).

\section{HASIL DAN PEMBAHASAN}

\section{Pelaksanaan Pembelajaran Sejarah di SMA Negeri 30 Jakarta}

Sebelum melihat kemampuan guru dalam penerapan literasi sejarah pada pembelajaran sejarah di SMA Negeri 30 Jakarta, peneliti terlebih dahulu melihat proses pembelajaran sejarah yang saat ini dilakukan jarak jauh secara daring. Sesuai dengan Keputusan Menteri Pendidikan dan Kebudayaan Republik Indonesia Nomor 719/P/2020 tentang Pedoman Pelaksanaan Kurikulum pada Satuan Pendidikan dalam Kondisi Khusus. Satuan pendidikan dalam kondisi khusus dapat menggunakan kurikulum darurat yang sesuai dengan kebutuhan pembelajaran peserta didik (Pengelola Web Kemendikbud, 2020). Pelaksanaan pembelajaran sejarah dalam satu kali pertemuan diberikan alokasi waktu 30 menit x 2 jam pelajaran.

Penyesuaian pelaksanaan pembelajaran terlihat jelas oleh peneliti ketika melakukan pengamatan dalam pembelajaran sejarah di Kelas X IPS 3 yang diampu oleh IM sebagai informan kunci dalam pengumpulan data, yaitu pelaksanaan pembelajaran menggunakan Google Meet dan Zoom Meeting, serta menggunakan aplikasi komunikasi pesan teks dan suara Whatsapp Group (WAG). Selain kedua aplikasi tersebut pihak sekolah 
juga menyediakan fasilitas pemberian tugas, pengumpulan tugas dan hasil ujian maupun materi secara daring melalui platform Learning Management System (LMS) milik SMA Negeri 30 Jakarta yaitu E-Learning. Untuk penggunaan aplikasi video conference Google Meet dan Zoom Meeting menurut IM dilakukan sesuai dengan kondisi siswa SMA Negeri 30 Jakarta. Keterbatasan akses jaringan dan kuota data siswa membuat pembelajaran secara bertatap maya hanya dilakukan 2 minggu sekali. Selebihnya menggunakan WAG dan E-learning (IM, 2020).

Sebelum melaksanakan pembelajaran jarak jauh (PJJ) daring, guru mempersiapkan rencana pembelajaran dengan menyusun Rencana Pelaksanaan Pembelajaran (RPP) satu lembar. Menurut Surat Edaran Menteri Pendidikan dan Kebudayaan Republik Indonesia Nomor 14 Tahun 2019 tentang Penyederhanaan Rencana Pelaksanaan Pembelajaran (RPP) merupakan salah satu kebijakan Merdeka Belajar Menteri Pendidikan dan Kebudayaan (SE Mendikbud) Nadiem Makarim. Menurut Mendikbud, inisiatif penyederhanaan RPP ini untuk meringankan beban administrasi guru. RPP yang sebelumnya terdiri dari belasan komponen, kini disederhanakan menjadi tiga komponen inti yang dapat dibuat hanya dalam satu halaman (Mayudana \& Sukendra, 2020). Selain itu, mekanisme ketentuan proses belajar dari rumah yang tertera dalam SE Mendikbud Nomor 4 Tahun 2020 tentang Pelaksanaan Kebijakan Pendidikan dalam Masa Darurat Penyebaran Covid-19, yakni pertama, memberikan pengalaman belajar yang bermakna bagi siswa tanpa terbebani penuntasan kurikulum; kedua, fokus pada pendidikan kecakapan hidup, yang menekankan pada keterampilan untuk beradaptasi; ketiga yakni aktivitas dan tugas disesuaikan dengan minat 
dan kondisi masing-masing siswa; terakhir, evaluasi siswa/ siswi bersifat kualitatif, bukan kuantitatif, sehingga laporan belajar bukan hanya dalam bentuk angka, melainkan penjelasan seberapa jauh murid memahami materi mereka (Insyiroh, Hariani, \& Mubaroq, 2020).

Dari hasil pengamatan di lapangan IM telah menjalankan mekanisme yang sesuai dengan kebijakan PJJ terkait dengan proses pembelajaran sejarah. Menurut IM, pelaksanaan pembelajaran sejarah pada masa PJJ lebih menekankan pada nilai kebermaknaan yang akan didapat siswa dalam pembelajaran. IM menyesuaikan materi-materi dengan penjelasan yang sederhana namun mudah untuk dipahami siswa (IM, 2020).

Pola pembelajaran konvensional tatap muka, yang diubah menjadi pola PJJ dengan memanfaatkan teknologi tentu banyak menghadapi kendala ketercapaian penyebaran dan pemahaman terkait materi ajar (Hariani \& Wastuti, 2020). Terdapat beberapa kendala yang dihadapi guru maupun siswa dalam PJJ. Kesulitan yang dialami guru adalah pengaturan waktu yang sesuai dengan materi yang akan diajarkan. Selain itu keaktifan siswa juga menjadi kendala guru dalam pelaksanaan pembelajaran sejarah dimasa PJJ.

Kesulitan yang dialami siswa lebih merujuk pada pelaksanaan PJJ. Menurut siswa yang diwawancarai peneliti, mereka kesulitan untuk fokus menyerap materi yang disampaikan oleh guru karena hanya bertemu secara daring. Pembelajaran di rumah membuat mereka merasa jenuh dengan situasi dan kondisi pembelajaran. Jika guru tidak mampu untuk menghadirkan pembelajaran sejarah yang menarik selama masa PJJ maka siswa akan kehilangan kebermaknaan dalam pembelajaran sejarah. 
Disinilah dibutuhkan kemampuan guru dalam menerapkan literasi sejarah dalam pembelajaran sejarah agar proses transfer nilai-nilai dalam pembelajaran sejarah memunculkan kebermaknaan mengenai pengetahuan dan pemahaman konseptual bukan hanya kegiatan menghafal semata.

\section{Penerapan Literasi Sejarah dalam Pembelajaran Sejarah di SMA Negeri}

\section{Jakarta}

Dalam penelitian ini berfokus pada penguasaan dan pemahaman guru mengenai literasi sejarah yang diterapkan dalam pembelajaran sejarah. Dari hasil penelitian yang dilakukan, IM menjelaskan bahwa konsep literasi sejarah belum familier dikalangan guru. Mengenai konsep literasi sejarah menurut IM adalah kemampuan mengetahui dan memahami adanya perubahan dan kontinuitas dalam sejarah dan menjadi manusia yang lebih terbuka untuk mempelajari sejarah. Lebih lanjut IM menjelaskan cara mengetahui tentang satu buah peristiwa sejarah dan memahaminya adalah dengan membaca beraneka ragam literatur atau beraneka ragam sumber seperti buku-buku, tesis, disertasi, ataupun artikel-artikel relevan dari internet. Hal ini membuat siswa akan lebih kaya dalam memandang satu buah permasalahan khususnya dalam materi-materi sejarah. Pendapat IM mengenai konsep literasi sejarah merujuk pada konsep literasi secara tradisional yaitu membaca beraneka ragam teks atau bacaan untuk memahami suatu peristiwa sejarah. Pendapat IM sejalan dengan pendapat Ahonen (2005) yang memandang literasi sejarah adalah kemahiran dalam membaca dan mendiskusikan sejarah. Jika seseorang mampu mempertanyakan bukti dan penjelasan sejarah, maka orang tersebut dianggap telah memahami konsep-konsep 
dasar sejarah (Zahroh, 2014). Untuk itu guru sejarah dihadapkan dengan banyak keputusan terkait literasi sejarah dalam perencanaan pembelajaran mereka. Keputusan terkait literasi sejarah akan dipengaruhi oleh faktor sumber daya yang tersedia di sekolah dan sejauh mana pengetahuan atau penguasaan guru tersebut mengenai konsep literasi sejarah (Nokes, 2010).

Selain pengetahuan dan penguasaan guru terhadap konsep literasi sejarah dalam pembelajaran sejarah, penguasaan siswa dalam hal berliterasi juga mempengaruhi guru dalam menerapkan literasi sejarah. Pada kasus di SMA Negeri 30 Jakarta ini guru melihat bahwa kemampuan literasi siswa masih sangat minim. Temuan di lapangan menunjukan bahwa siswa-siswa berpandangan belajar sejarah lebih pada kegiatan membaca buku teks dan menghafal peristiwa-peristiwa dalam buku teks. Persoalan klasik pembelajaran sejarah di sekolah adalah adanya citra yang sangat kuat di kalangan siswa bahwa mata pelajaran sejarah adalah mata pelajaran sejarah bersifat hafalan, kurang menarik, dan membosankan (Sayono, 2013). Siswa tidak dibiasakan untuk mengartikan suatu peristiwa guna memahami dinamika suatu perubahan (Purnamasari \& Wasino, 2011).

Persoalan ini menjadi semakin kompleks dengan dilakukannya PJJ. Kurangnya fokus siswa selama PJJ memaksa guru untuk menciptakan pembelajaran sejarah yang menarik dan kreatif. IM kemudian mencoba menerapkan literasi (sejarah) dalam proses pembelajaran dan pemberian tugas mingguan maupun tugas semester. Guru membuat pembelajaran berbasis proyek literasi dengan menggabungkan mata pelajaran sejarah dengan mata pelajaran lain seperti mata pelajaran Bahasa Indonesia, Seni, 
Bahasa Inggris, dan Geografi. Pada setiap mata pelajaran tersebut akan dikaitkan dengan penelitian sejarah, contohnya untuk penggabungan mata pelajaran seni dan sejarah, guru seni akan memberikan tugas praktik menari sesuai dengan pilihan jenis tari dari siswa dan guru sejarah akan memberikan tugas mencari informasi-informasi lengkap seputar tari yang akan diperagakan siswa kemudian menuliskannya menjadi sebuah tulisan sejarah dan diceritakan kembali. Hal ini sangat menarik minat siswa dan menjadikan siswa dapat belajar sejarah dari berbagai sumber dan materi seperti materi sejarah seni tari. Hal ini akan dilakukan IM mata pelajaran lain yang tergabung dalam proyek literasi. Selain itu IM juga mengarahkan siswa untuk dapat mencari sumber-sumber relevan dari berbagai buku teks dan artikel-artikel internet. Lebih lanjut IM juga sering memberikan siswa tugas untuk melakukan bedah buku dalam skala kecil dari e-book yang diberikan kepada siswa sebagai bahan bacaan terkait materi.

Selanjutnya terkait dengan penerapan literasi sejarah sesuai dengan kerangka konseptual literasi sejarah menurut Maposa dan Wasserman (2009), IM telah menunjukan bahwa memiliki penguasaan terhadap kerangka konsep literasi sejarah yang diterapkan dalam pembelajaran sejarah sesuai dengan 2 dimensi yang menjadi tolok ukur dalam penelitian ini yaitu :

\section{Pengetahuan konten sejarah}

Pengetahuan konten sejarah yang pada gilirannya terdiri dari peristiwa sejarah dan narasi sebagai sub-dimensi. Guru harus memiliki kemampuan mengenai peristiwa-peristiwa sejarah dan narasi-narasi sejarah sebagai kemampuan dasar untuk menjelaskan berbagai materi 
sejarah yang telah disusun dalam silabus pembelajaran sejarah. Guru harus mampu untuk menyajikan peristiwa-peristiwa sejarah yang sesuai dengan konteks materi yang dipelajari agar siswa bisa memahami lebih dalam dan dapat berpikir secara kritis mengenai peristiwa yang dipelajari. Dari aspek ini dapat dikatakan IM telah memiliki pengetahuan konten sejarah yang sangat baik. Hal ini terlihat pada saat observasi pertama yang menunjukan IM mampu menjelaskan contoh-contoh mengenai peristiwa-peristiwa dan narasi-narasi sejarah dalam materi Historiografi Sejarah. IM mampu menjelaskan peristiwa-peristiwa dan narasi-narasi sejarah yang termasuk dalam historiografi tradisional, kolonial dan modern. Selain materi tersebut, pada saat dilakukan wawancara IM menunjukkan penguasaannya terhadap materi-materi sejarah lainnya seperti materi sejarah nasional mulai dari zaman prasejarah, zaman hindu-budha, masa kolonial, pergerakan nasional, dan materi lainnya.

2. Pemahaman konseptual dalam sejarah

Pemahaman konseptual dalam sejarah dengan sub-dimensinya adalah waktu, sebab dan akibat, motivasi, signifikansi, perubahan dan kontinuitas, empati, dan penilaian moral. Dari hasil pengamatan di lapangan dan hasil wawancara yang dilakukan dengan guru sejarah sebagai informan sudah menunjukkan penguasaan pada semua subdimensi dari pemahaman konseptual tersebut.

Sejarah adalah ilmu tentang manusia dalam dimensi waktu dan tempat (ruang). Sejarah tidak mempelajari masa lampau sebagai objek studinya, tetapi ilmu sejarah mempelajari sumber-sumber sejarah atau peninggalan dari masa lampau seperti dokumen, arsip, catatan, dan informasi serta kesaksian lisan (Sulaiman, 2012). Pemahaman guru 
mengenai pentingnya literasi sejarah dalam menjelaskan konsep waktu dalam sejarah, ditunjukkan guru dalam hasil wawancara. Menurut guru dengan literasi sejarah peserta didik dapat memiliki keterampilan dasar dalam menghubungkan antara satu peristiwa sejarah dengan konsep ruang dan waktu kejadian satu buah peristiwa sejarah lainnya. Siswa akan mampu melihat berbagai peristiwa dari sudut pandang berbeda tergantung waktu dan ruang terjadinya peristiwa tersebut.

Sub-dimensi kedua adalah sebab-akibat (kausalitas) dan konsekuensi, Plato berpendapat bahwa segala sesuatu yang terjadi dan berubah mestilah ada sebabnya karena tak ada di dunia ini yang terjadi tanpa sebab. Konsep "sebab" dalam sejarah mengacu pada tindakan atau kejadian yang dapat menyebabkan terjadinya tindakan atau peristiwa lain. Hasil dari tindakan atau kejadian itu disebut akibat. Hubungan sebab-akibat melibatkan korelasi yang selalu dapat dipelajari. Tanpa konsep sebab-akibat sejarah akan kehilangan ciri ilmiahnya. Konsep sebab dalam sejarah selalu mendahului akibat atau sebaliknya akibat selalu merupakan hasil dari tindakan atau peristiwa sebelumnya (Zed, 2018). Hal ini sejalan dengan pandangan IM, menurutnya belajar sejarah sangat penting untuk mengetahui sebabakibat suatu peristiwa sejarah agar belajar sejarah bukan hanya menyajikan fakta-fakta kering tetapi juga kebermaknaan nilai dari suatu peristiwa yang dipelajari. Seperti contohnya guru memberikan penugasan kepada siswa untuk mencari sebab-akibat dari peristiwa Perang Diponegoro yang memberikan informasi bahwa suatu peristiwa perang yang terjadi pasti ada sebab pemicunya dan akan ada akibat dari peristiwa perang tersebut. 
Selanjutnya kemampuan guru dalam memberikan motivasimotivasi terkait dengan pembelajaran sejarah. Pada sub-dimensi ini, guru telah menerapkannya dengan sangat baik. Motivasi diberikan guru bukan hanya terkait dengan motivasi belajar sejarah akan tetapi motivasi agar dapat menerapkan arti penting sejarah dalam kehidupan sehari-hari. Menurut guru arti penting dalam pembelajaran sejarah dapat dijadikan bekal bagi siswa untuk diterapkan dalam kehidupan sehari-hari. IM selalu memberikan peristiwa-peristiwa sejarah atau materi-materi pembelajaran sejarah yang dikaitkan dengan keadaan kontekstual permasalahanpermasalahan pada masa kini yaitu masalah-masalah sosial ataupun masalah-masalah dari masa lalu yang masih berlanjut dan diperbincangkan sampai saat ini. Memberikan peristiwa-peristiwa sejarah yang masih faktual dapat dibahas sampai masa sekarang juga akan mengarahkan siswa untuk mengambil penilaian moralnya sendiri terkait suatu peristiwa. IM melakukan proses berliterasi sejarah dengan mengarahkan siswa untuk membaca berbagai sumber-sumber sejarah kemudian siswa diberikan kesempatan untuk memberikan argumen sehingga siswa dapat memberikan penilaian moralnya tersendiri terkait dengan peristiwa-peristiwa yang dibacanya.

Sub-dimensi berikutnya adalah konsep perubahan dan keberlanjutan. Sejarah selalu berkenaan dengan perubahan dan perubahan selalu berlangsung dalam waktu, karena waktu adalah variabel yang esensial dalam sejarah. Perubahan di sini maksudnya tidak hanya berkenaan dengan peristiwa sejarah itu sendiri, tetapi cara pandang kita terhadap sejarah juga mengalami perubahan. Pada saat yang sama kontinuitas (keberlanjutan) juga merupakan bagian yang integral dari 
perubahan dalam perjalanan waktu. Dalam proses pelaksanaan pembelajaran sejarah IM telah mampu menghadirkan konsep perubahan dan keberlanjutan dalam materi sejarah. Guru selalu menekankan dalam pembelajarannya bahwa kehidupan manusia selalu berubah sehingga peristiwa sejarah mengikuti perubahan dari manusia itu sendiri. Selain mengalami perubahan, peristiwa sejarah juga mengalami keberlanjutan sehingga guru selalu mengaitkan konteks peristiwa sejarah masa lalu yang masih terjadi pada masa saat ini. Menurut guru dalam penjelasannya, yang dimaksud berkelanjutan bukan peristiwanya tetapi pola dari peristiwa dimasa lalu yang masih bisa ditemui di masa sekarang.

Sub-dimensi terakhir dari konsep literasi sejarah adalah empati. Jenkins dan Brickley (1989) yang mengatakan bahwa sangat memungkinkan bagi seorang guru untuk membiarkan siswanya menemukan makna dari empati sejarah dengan sendirinya melalui pembelajaran sejarah (Harris, 2016). Dalam memunculkan rasa empati siswa, guru selalu mengaitkan dengan peristiwa-peristiwa masa sekarang. Misalnya membahas mengenai kolonialisme dan imperialisme guru selalu mengaitkan dengan imperialisme modern yang terjadi pada masa sekarang. Guru selalu mengkaitkan dengan contohnya produk-produk impor yang masuk ke dalam Indonesia sehingga secara tidak langsung siswa itu merasa tersadar dan tergugah dengan rasa empati mereka bahwa hal ini terjadi seperti kondisi negara Indonesia dan mereka akan membayangkan peristiwa-peristiwa yang terjadi dimasa lalu lebih buruk dari yang terjadi saat ini. Hal ini bisa terjadi jika literasi sejarah yang diterapkan guru sudah sesuai sehingga membawa pemahaman 
beranekaragam aspek dalam pola pemikiran siswa, dengan demikian mereka bisa berpikir kritis dalam membahas ataupun mengambil kesimpulan dari sebuah peristiwa sejarah.

\section{KESIMPULAN}

Dari hasil temuan dan pembahasan yang telah diuraikan, menunjukkan bahwa guru memiliki penguasaan terhadap aspek penting yang menjadi kerangka konseptual literasi sejarah yang diterapkan dalam pembelajaran sejarah sesuai dengan dua dimensi yang menjadi tolok ukur dalam penelitian yaitu literasi sejarah Maposa dan Wasserman (2009). Akan tetapi, dari segi pemahaman konseptual guru mengenai konsep literasi sejarah masih kurang detail dikarenakan konsep literasi sejarah yang masih belum familier di Indonesia khususnya dikalangan guru sejarah serta guru menganggap konsep literasi sejarah sama dengan literasi tradisional, sehingga guru kemudian mencoba mengembangkan literasi sejarah menurut pandangannya yaitu mengkaitkan dengan kemampuan mengetahui dan memahami sebuah peristiwa sejarah, sebab pemahaman tentang adanya perubahan dan kontinuitas dari waktu ke waktu harus dapat menjadikan manusia yang lebih terbuka.

Cara agar siswa mengetahui dan memahami tentang suatu peristiwa sejarah adalah dengan membaca beraneka ragam literatur. Penerapan literasi sejarah di SMA Negeri 30 Jakarta juga disesuaikan dengan kondisi pembelajaran saat ini yang dilakukan secara daring. Penerapan literasi sejarah yang dilakukan pada masa PJJ salah satunya ditunjukkan dari pemberian tugas dengan penugasan berbasis proyek yaitu penggabungan mata pelajaran sejarah dengan mata pelajaran lain. 


\section{DAFTAR PUSTAKA}

Clifford, G. J. (1984). Buch und Lesen: Historical Perspectives on Literacy and Schooling. Review of Educational Research, 54(4), 472-500. https://doi.org/10.3102/00346543054004472

Hariani, P. P., \& Wastuti, S. N. Y. (2020). Pemanfaatan E-Learning pada Pembelajaran Jarak Jauh di Masa Pandemi Covid-19. Biblio Couns :Jurnal Kajian Konseling Dan Pendidikan, 3(2), 41-49.

Harris, K. B. (2016). Teacher Strategies for Developing Historical Empathy. Retrieved from https://search-proquestcom.dbgw.lis.curtin.edu.au/docview/1853862278? accountid=10382

IM. (2020). Personal Interview with History Teacher in SMA Negeri 30 Jakarta. Jakarta: Not Published.

Insyiroh, I. M., Hariani, E. P., \& Mubaroq, S. (2020). Pendidikan Berbasis Kearifan Lokal sebagai Solusi Menghadapi Kesenjangan Digital dalam Kebijakan Pembelajaran Jarak Jauh pada Masa Pandemi di Indonesia. Indonesian Journal of Social Development, 1(1), 51-72. Retrieved from https://jurnal.apsindo.org/index.php/ijsd/index

Lee, P. (2004). Historical Literacy: Theory and Research. Internasional Journal of Historical Learning, Teaching and Research, 5(1), 1-12.

Maposa, M., \& Wassermann, J. (2009). Conceptualising historical literacy a review of the literature. Yesterday $\mathcal{E}$ Today, (4), 41-66.

Mayudana, I. K. Y., \& Sukendra, I. K. (2020). Analisis Kebijakan Penyederhanaan RPP (Surat Edaran Menteri Pendidikan Dan Kebudayaan Nomor 14 Tahun 2019). IJED (Indonesian Journal of Educational Development), 1(1), 61-68. https://doi.org/10.5281/zenodo.3760682

Milles, M. B., \& Huberman, M. A. (1994). Qualitative Data Analysis : An Expanded Sourcebook. London: Sage Publications.

Nokes, J. D. (2010). Observing literacy practices in history classrooms. Theory and Research in Social Education, 38(4), 515-544. https://doi.org/10.1080/00933104.2010.10473438

Pengelola Web Kemendikbud. (2020). Kemendikbud Terbitkan Kurikulum Darurat pada Satuan Pendidikan dalam Kondisi Khusus. Retrieved from Kementerian Pendidikan dan Kebudayaan website: https://www.kemdikbud.go.id/main/blog/2020/08/kemendikbudterbitkan-kurikulum-darurat-pada-satuan-pendidikan-dalam- 
kondisi-khusus

Prawiyogi, A. G., Purwanugraha, A., Fakhry, G., \& Firmansyah, M. (2020). Efektifitas Pembelajaran Jarak Jauh Terhadap Pembelajaran Siswa di SDIT Cendekia Purwakarta. Jurnal Pendidikan Dasar, 11(01), 94-101.

Purnamasari, I., \& Wasino, W. (2011). Pengembangan Model Pembelajaran Sejarah Berbasis Kabupaten Temanggung. Paramita - Historical Studies Journal, 21(2), 202-212.

Sayono, J. (2013). Pembelajaran Sejarah Di Sekolah: Dari Pragmatis Ke Idealis. Jurnal Sejarah Dan Budaya, 7(1), 109-123. Retrieved from http://journal.um.ac.id/index.php/sejarah-danbudaya/article/view/4733

Sugiyono. (2014). Memahami Pendekatan Kualitatif. Bandung: Penerbit Alfabeta.

Sulaiman, S. (2012). Pendekatan konsep dalam pembelajaran sejarah. Jurnal Sejarah Lontar, 9(1). Retrieved from http://journal.unj.ac.id/unj/index.php/lontar/article/view/2373/1816

Yin, R. K. (2011). Studi Kasus : Desain dan Metode (M. D. Mudzakir, Ed.). Jakarta: Rajawali Press.

Zahroh, N. L. (2014). Pemanfaatan Situs Singosari dalam Mengembangkan Literasi Sejarah Peserta Didik. Jurnal Pendidikan Ilmu Pengetahuan Sosial (J-PIPS), 165-196. Retrieved from Jurnal Pendidikan Ilmu Pengetahuan Sosial (J-PIPS)

Zed, M. (2018). Tentang Konsep Berfikir Sejarah. Lensa Budaya: Jurnal Ilmiah Ilmu-Ilmu Budaya, 13(1), 54-60.

https://doi.org/http://dx.doi.org/10.34050/jlb.v13i1.4147 